\title{
Three Chiral Cyanide-Bridged Cr-Cu Complexes: Synthesis, Crystal Structures and Magnetic Properties
}

\author{
Xia Chen, ${ }^{1,+}$ Wen-Long Lan, ${ }^{1,+}$ Xiao-Yun Hao, ${ }^{1}$ Yu Liu, ${ }^{1}$ Zhen Zhou, \\ Shu-Juan Zhuang, ${ }^{1}$ Lu Yang, ${ }^{1}$ Qing-Yun Liu, ${ }^{2}$ Wei-Jiang $\mathrm{Si}^{1}{ }^{1}{ }^{*}$ \\ and Dao-Peng Zhang ${ }^{1{ }^{*}}$ \\ ${ }^{1}$ College of Chemical and Chemical Engineering, Shandong University of Technology, Zibo 255049, PR China \\ ${ }^{2}$ College of Chemical and Environmental Engineering, Shandong University of Science and Technology, \\ Qingdao 266510, PR China
}

*Corresponding author: E-mail: siweijiang@sdut.edu.cn,dpzhang73@126.com

${ }^{+}$These two authors contributed equally.

Received: $12-05-2018$

\begin{abstract}
Two trans-dicyanidochromium(III)-containing building blocks and one chiral copper(II) compound have been employed to assemble cyanide-bridged heterometallic complexes, resulting in three chiral cyanide-bridged $\mathrm{Cr}(\mathrm{III})-\mathrm{Cu}(\mathrm{II})$ complexes, $\left\{\left[\mathrm{Cu}\left(\mathrm{L}^{1}\right)_{2} \mathrm{Cr}\left(\mathrm{L}^{3}\right)(\mathrm{CN})_{2}\right] \mathrm{ClO}_{4}\right\}_{2} \cdot \mathrm{CH}_{3} \mathrm{OH} \cdot \mathrm{H}_{2} \mathrm{O}\left(\mathbf{1 a}, \mathrm{L}^{1}=(S, S)\right.$-1,2-diaminocyclohexane, $\mathrm{H}_{2} \mathrm{~L}^{3}=1$,2-bis(pyridine-2-carboxamido)benzene), $\left\{\left[\mathrm{Cu}\left(\mathrm{L}^{2}\right)_{2} \mathrm{Cr}\left(\mathrm{L}^{2}\right)(\mathrm{CN})_{2}\right] \mathrm{ClO}_{4}\right\}_{2} \cdot \mathrm{CH}_{3} \mathrm{OH} \cdot \mathrm{H}_{2} \mathrm{O}\left(\mathbf{1 b}, \mathrm{L}^{2}=(R, R)\right.$-1,2-diaminocyclohexane $)$ $\left\{\left[\mathrm{Cu}\left(\mathrm{L}^{3}\right)_{2} \mathrm{Cr}\left(\mathrm{L}^{4}\right)(\mathrm{CN})_{2}\right]\left[\mathrm{Cr}\left(\mathrm{L}^{4}\right)(\mathrm{CN})_{2}\right]\right\} \cdot \mathrm{CH}_{3} \mathrm{OH} \cdot 2 \mathrm{H}_{2} \mathrm{O}(2),\left(\mathrm{H}_{2} \mathrm{~L}^{4}=1,2\right.$-bis(pyridine-2-carboxamido)-4-chlorobenzene). All the three complexes have been characterized by elemental analysis, IR spectroscopy and X-ray structure determination. Single-crystal X-ray diffraction analysis shows that the two enantiomeric complexes $\mathbf{1 a}, \mathbf{1 b}$ and the complex $\mathbf{2}$ belong to cyanide-bridged cationic binuclear structure type with $\mathrm{ClO}_{4}{ }^{-}$or the anionic cyanide building block as balance anion for complexes $\mathbf{1 a}, \mathbf{1} \mathbf{b}$ or $\mathbf{2}$, respectively. Investigation of the magnetic properties of the complexes $\mathbf{1 a}$ and $\mathbf{2}$ reveals the weak ferromagnetic coupling between the neighboring $\mathrm{Cr}(\mathrm{III})$ and $\mathrm{Cu}(\mathrm{II})$ ions through the bridging cyanide group.
\end{abstract}

Keywords: Chiral; cyanide-bridged; heterobimetallic; crystal structure; magnetic property

\section{Introduction}

Molecular-based magnetic materials have attracted widespread attention in the past few decades due to their potential applications in high-density information storage and quantum tunneling effects. ${ }^{1-4}$ During the process of the synthesis of the new magnetic complexes, the choice of magnetic spin carriers, bridging bonds and coordination ligands plays a very important role on the structure and the functional property of the target magnetic complexes. Among which, as one of the well-known magnetic transfer groups, cyanide groups usually exhibit unique advantages when assembling bimetallic or even trimetallic cyanide-bridged magnetic complexes. ${ }^{5-16}$ Although there are many combinations of different magnetic carriers for cyanide-bridged complexes, the $\mathrm{Cr}^{\mathrm{III}}$-Cu${ }^{\mathrm{II}}$ system still receives much attention and many cyanide-bridged $\mathrm{Cr}^{\mathrm{III}}-\mathrm{Cu}^{\mathrm{II}}$ complexes with interesting magnetic properties such as sin- gle-molecule magnets, single-chain magnets, spin crossover magnets and photo switchable magnets have been reported. ${ }^{17-20}$ Compared with the cyanide-bridged heterometallic Fe ${ }^{\mathrm{III}}-\mathrm{M}(\mathrm{M}=\mathrm{Cu}(\mathrm{II}), \mathrm{Ni}(\mathrm{II}), \mathrm{Mn}(\mathrm{II}), \mathrm{Mn}(\mathrm{III})$, et al.) complexes, ${ }^{21-27}$ the cyanide-bridged heterometallic $\mathrm{Cr}^{\mathrm{III}}-\mathrm{M}$ complexes are still limited due to the shortage of stable and suitable cyanidochromate(III) building blocks. ${ }^{28-32}$

In recent years, in order to clearly clarify the magnetic structure correlation in low-dimensional magnetic systems and to prepare interesting low-dimensional molecular magnetic materials, a series of cyanide precursors containing the larger equatorial in-plane ligands and two trans-cyanide groups have been designed. ${ }^{33-38}$ Studies have shown that these types of cyanide-containing precursors were good choices for assembling cyanide bridged bimetallic magnetic complexes with different structures, such as multinuclear, nanomolecular and one-dimension- 
al chains, and interesting magnetic properties. On the other hand, in the research field of functional molecular magnetic materials, the design and synthesis of chiral magnetic materials are of great significance for the basic research of magnetic induction second harmonic generation (MSHG) and magnetic chiral dichroism (MCHD) and their possible applications in a variety of new technologies. It is known that the chirality can be reasonably introduced into the cyanide bridging system by coordinating the paramagnetic metal ions $\left(\mathrm{Ni}^{2+}, \mathrm{Cu}^{2+}, \mathrm{Mn}^{2+/ 3+}\right.$, etc) with a chiral auxiliary ligand (chiral amine, chiral Schiff base, etc.). ${ }^{39-46}$ In order to find new chiral molecular magnetic complexes and further enrich the low-dimensional cyanide bridged trans-dicyano-based compounds, we investigated the reactions of trans-dicyanidochromium(III) precursors with chiral organic amine copper compounds (Scheme 1) and obtained three new cyanide-bridged chiral $\mathrm{Cr}(\mathrm{III})-\mathrm{Cu}(\mathrm{II})$ complexes, including the two enantiomeric complexes $\left\{\left[\mathrm{Cu}\left(\mathrm{L}^{1 /} / \mathrm{L}^{2}\right)_{2} \mathrm{Cr}\left(\mathrm{L}^{3}\right)(\mathrm{CN})_{2}\right] \mathrm{ClO}_{4}\right\}_{2} \cdot \mathrm{CH}_{3} \mathrm{OH} \cdot \mathrm{H}_{2} \mathrm{O}(\mathbf{1 a}, \mathbf{1 b})$, and $\left\{\left[\mathrm{Cu}\left(\mathrm{L}^{2}\right)_{2} \mathrm{Cr}\left(\mathrm{L}^{4}\right)(\mathrm{CN})_{2}\right]\left[\mathrm{Cr}\left(\mathrm{L}^{4}\right)(\mathrm{CN})_{2}\right]\right\} \cdot \mathrm{CH}_{3} \mathrm{OH}$. $2 \mathrm{H}_{2} \mathrm{O}$ (2). This paper will mainly concern the synthesis, crystal structures and magnetic properties for the above three complexes.

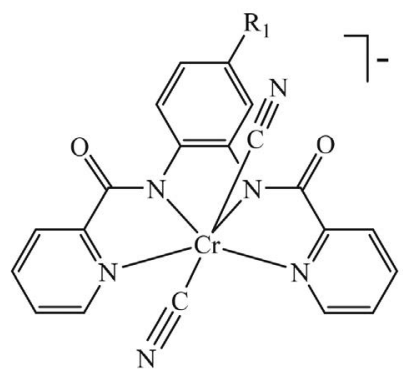

trans- $\left[\mathrm{Cr}^{\mathrm{III}}\left(\mathrm{L}^{3} / \mathrm{L}^{4}\right)(\mathrm{CN})_{2}\right]^{-}$ $\left[\mathrm{L}^{3}, \mathrm{R}_{1}=\mathrm{H} ; \mathrm{L}^{4}, \mathrm{R}_{1}=\mathrm{Cl}\right]$

Scheme 1. The starting materials used for synthesizing the three complexes.

\section{Experimental}

Elemental analyses of carbon, hydrogen, and nitrogen were carried out with an Elementary Vario El. The infrared spectroscopy on $\mathrm{KBr}$ pellets was performed on a Magna-IR 750 spectrophotometer in the $4000-400 \mathrm{~cm}^{-1}$ region. Variable-temperature magnetic susceptibilities for the reported complexes were performed on a Quantum Design MPMS SQUID magnetometer. The experimental susceptibilities were corrected for the diamagnetism of the constituent atoms (Pascal's tables).

\section{1. General Procedures and Materials}

All the reactions were carried out under an air atmosphere and all chemicals and solvents used were reagent grade without further purification. $\mathrm{K}\left[\mathrm{Cr}^{\mathrm{III}}\left(\mathrm{L}^{3}\right)(\mathrm{CN})_{2}\right]$ $\left[\mathrm{H}_{2} \mathrm{~L}^{3}=1,2\right.$-bis(pyridine-2-carboxamido)benzene] was synthesized as described in literature. ${ }^{47}$ The synthesis of another cyanide precursor is similar to that for $\mathrm{K}\left[\mathrm{Cr}{ }^{\mathrm{III}}\left(\mathrm{L}^{3}\right)\right.$ $(\mathrm{CN})_{2}$ ], except that the 1,2-diamino-4-chlorobenzene was used to replace 1,2-diaminobenzene during the preparation process. The two chiral 1,2-diaminocyclohexane were from the J\&K Scientific LTD.

Caution! KCN is hypertoxic and hazardous. Perchlorate salts of metal complexes with organic ligands are potentially explosive. These chemicals should be handled in small quantities with great care.

\section{2. Preparation of the Complexes $1 \mathrm{a}, 1 \mathrm{~b}$ and 2}

All three complexes were prepared using similar procedure. Therefore, a representative method for preparation of the complex 1a is described herein.

Complex 1a was prepared by the following procedures: The acetonitrile solution $(10 \mathrm{~mL})$ formed in situ by $\left[\mathrm{Cu}\left(\mathrm{ClO}_{4}\right)_{2}\right] \cdot 6 \mathrm{H}_{2} \mathrm{O}(36.5 \mathrm{mg}, 0.1 \mathrm{mmol})$ and $\mathrm{L}^{1}(22.8 \mathrm{mg}$, $0.2 \mathrm{mmol})$ was added slowly to a solution containing $\mathrm{K}\left[\mathrm{Cr}\left(\mathrm{L}^{3}\right)(\mathrm{CN})_{2}\right](91.6 \mathrm{mg}, 0.20 \mathrm{mmol})$ dissolved in a mixture of methanol and water $(8 \mathrm{~mL}: 2 \mathrm{~mL})$. The mixture was stirred only for one minute at room temperature and filtered at once to remove any insoluble material, and then the filtrate was allowed to evaporate slowly without disturbance for about one week. The dark-orange crystals generated suitable for X-ray diffraction were collected by filtration, washed with cool methanol, and dried in air. Yield: $44.3 \mathrm{mg}, 53.1 \%$. Anal. Calcd. for $\mathrm{C}_{65} \mathrm{H}_{86} \mathrm{Cl}_{2} \mathrm{Cr}_{2} \mathrm{Cu}_{2} \mathrm{~N}_{20} \mathrm{O}_{14}$ : C, 46.65; H, 5.18; N, 16.74. Found: C, 46.87; H, 5.26; N, 16.59. Main IR bands $\left(\mathrm{cm}^{-1}\right): 3330,3295(\mathrm{~s}, \mathrm{nN}-\mathrm{H}), 2160$, $2130\left(\mathrm{~s}, \mathrm{nC}^{\circ} \mathrm{N}\right), 1100$ (vs, $\mathrm{nCl}=\mathrm{O}$ ).

Complex 1b: Yield: $42.7 \mathrm{mg}, 51.2 \%$. Anal. Calcd. for $\mathrm{C}_{65} \mathrm{H}_{86} \mathrm{Cl}_{2} \mathrm{Cr}_{2} \mathrm{Cu}_{2} \mathrm{~N}_{20} \mathrm{O}_{14}$ : C, 46.65; H, 5.18; N, 16.74 . Found: C, 46.89; H, 5.25; N, 16.61. Main IR bands $\left(\mathrm{cm}^{-1}\right)$ : 3330, 3296(s, nN-H), 2160, $2130\left(\mathrm{~s}, \mathrm{nC}^{\circ} \mathrm{N}\right.$ ), 1100 (vs, $\mathrm{nCl}=\mathrm{O})$.

Complex 2: Yield: $69.8 \mathrm{mg}, 55.1 \%$. Anal. Calcd. for $\mathrm{C}_{53} \mathrm{H}_{56} \mathrm{Cl}_{2} \mathrm{Cr}_{2} \mathrm{CuN}_{16} \mathrm{O}_{7}$ : C, 50.22; H, 4.45; N, 17.68. Found: C, 50.33; H, 4.59; N, 17.51. Main IR bands $\left(\mathrm{cm}^{-1}\right)$ : 3332, 3294(s, nN-H), 2158, 2127 (s, nCN).

\section{3. X-ray Data Collection and Structure Refinement}

Crystal data of three complexes were collected by using single-crystals with suitable dimensions on an Oxford

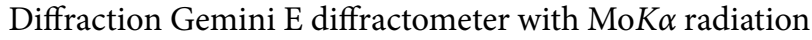
$(\lambda=0.71073 \AA)$ at room temperature, and the collected frames were integrated by using the preliminary cell-orientation matrix. The structures of these three complexes were solved by direct method and expanded using Fourier difference techniques with the SHELXTL-97 program package. ${ }^{48}$ All non-hydrogen atoms were readily located 
Table 1. Crystallographic data and structure refinement summary for the three complexes.

\begin{tabular}{lccc}
\hline & $\mathbf{1 a}$ & $\mathbf{1 b}$ & $\mathbf{2}$ \\
\hline Empirical formula & $\mathrm{C}_{65} \mathrm{H}_{86} \mathrm{Cl}_{2} \mathrm{Cr}_{2} \mathrm{Cu}_{2} \mathrm{~N}_{20} \mathrm{O}_{14}$ & $\mathrm{C}_{65} \mathrm{H}_{86} \mathrm{Cl}_{2} \mathrm{Cr}_{2} \mathrm{Cu}_{2} \mathrm{~N}_{20} \mathrm{O}_{14}$ & $\mathrm{C}_{53} \mathrm{H}_{56} \mathrm{Cl}_{2} \mathrm{Cr}_{2} \mathrm{CuN}_{16} \mathrm{O}_{7}$ \\
Formula weight & 1673.52 & 1673.52 & 1267.58 \\
Temperature (K) & 293 & 293 & 293 \\
Crystal system & Monoclinic & Monoclinic & Triclinic \\
Space group & $P 2_{1}$ & $P 21$ & $P 1$ \\
$a / \AA$ & $13.9564(9)$ & $13.934(10)$ & $10.8564(14)$ \\
$b / \AA$ & $12.2866(8)$ & $12.259(8)$ & $12.040(2)$ \\
$c / \AA$ & $22.6709(14)$ & $22.648(15)$ & $13.8215(17)$ \\
$\alpha /$ deg & 90 & 90 & $114.89(1)$ \\
$\beta /$ deg & $91.03(0)$ & $90.88(1)$ & $91.40(1)$ \\
$\gamma /$ deg & 90 & 90 & $105.46(1)$ \\
$F(000)$ & 1736.0 & 1736.0 & 653.0 \\
Reflections collected/unique & $19548 / 11239$ & $19286 / 10871$ & $11422 / 8226$ \\
Data/restraints/parameters & $11239 / 2 / 948$ & $10871 / 1 / 948$ & $8226 / 3 / 750$ \\
Goodness-of-fit on $F^{2}$ & 1.028 & 1.031 & 0.995 \\
$R_{1}[\mathrm{I}>2 \sigma(\mathrm{I})]$ & 0.0535 & 0.0545 & 0.0769 \\
$w R_{2}$ (all data) & 0.1475 & 0.1536 & 0.2233 \\
Largest diff. peak/ hole $\left(\mathrm{e} / \AA^{3}\right)$ & $0.622 /-0.296$ & $0.513 /-0.334$ & $0.778 /-0.347$ \\
\hline
\end{tabular}

and refined anisotropically. In ligand $\mathrm{L}^{4}$ in complex 2 chlorine atoms $\mathrm{Cl} 1$ and $\mathrm{Cl} 2$ were refined as disordered over two positions with 0.80:0.20 and 0.50:0.50 occupancy ratios, respectively. Hydrogen atoms were assigned isotropic displacement coefficients $U(\mathrm{H})=1.2 U(\mathrm{C})$ or $1.5 U(\mathrm{C})$ and their coordinates were allowed to ride on their respective carbon atoms or nitrogen atoms using SHELXL-97 except of the solvent $\mathrm{H}$ atoms. For the latter, they were refined isotropically with fixed $U$ values and the DFIX command was used to rationalize the bond parameter. CCDC 1861738-1861740 for these three complexes contain the supplementary crystallographic data for this paper, which can be obtained free of charge from the Cambridge Crystallographic Data Centre via www.ccdc.cam.ac.uk/data request/cif. Details of the crystal parameters, data collection, and refinement of complexes 1-2 are summarized in Table 1.

\section{Results and Discussion}

\section{1. Synthesis and General Characterization}

The recent works have proved that trans-dicyanometallates are good building blocks for synthesizing cyanide-bridged magnetic complexes. ${ }^{33-38}$ The relatively large planar pyridinecarboxamide ligand at the equatorial position can not only effectively lower the dimensionality of the resulted complex, but also weaken the supramolecular intermolecular magnetic interactions. With this in mind and also for the purpose of the preparation of chiral magnetic complexes, we investigated the reactions of trans-dicyanidochromium(III) with chiral amine copper(II) compounds and obtained three new chiral cyanide-bridged $\mathrm{Cr}(\mathrm{III})-\mathrm{Cu}(\mathrm{II})$ complexes. The different balance anions, i.e. $\mathrm{ClO}_{4}^{-}$for complexes $\mathbf{1 a}, \mathbf{1 b}$ and the cyanometallate for complexes $\mathbf{2}$ indicate that the structure of the cyanide precursor has some effects on the structure of the cyanide-bridged complex formed.

The three cyanide-bridged complexes have been characterized by IR spectroscopy. In the IR spectra of $\mathbf{1 a}$ and $\mathbf{1 b}$, two sharp peaks due to the cyanide-stretching vibration were observed at about 2125-2130 and 2155-2160 $\mathrm{cm}^{-1}$, respectively, indicating the presence of bridging and non-bridging cyanide ligands in these complexes. The strong broad peak centered at about $1100 \mathrm{~cm}^{-1}$ for these two complexes is attributed to the free $\mathrm{ClO}_{4}{ }^{-}$anion. To confirm the optical activity and enantiomeric nature, the circular dichroism (CD) spectrum were measured in $\mathrm{KBr}$ pellets for complexes 1-2. The CD spectrum of $\mathbf{1 a}$ and $\mathbf{1 b}$ exhibit positive and negative Cotton effect at the same wavelengths (Figure. 1).

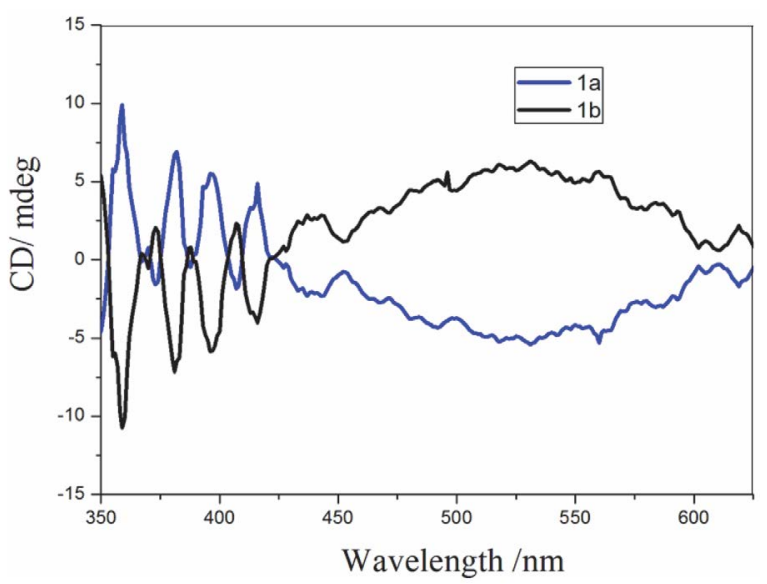

Figure 1. CD spectra of $\mathbf{1 a}$ ( $S$ isomer, black) and $\mathbf{1 b}$ ( $R$ isomer, blue) in $\mathrm{KBr}$ pellets. 


\section{2. Crystal structures of complexes $1 \mathrm{a}, 1 \mathrm{~b}$ and 2}

Some important structural parameters for complexes $\mathbf{1 a}, \mathbf{1 b}$ and $\mathbf{2}$ are collected in Table 2. The perspective view of the enantiomeric structure of complexes $\mathbf{1 a}$ and $\mathbf{1 b}$ is demonstrated in Figure 2. The cell packing diagram of the complex 1a is given in Figure 3, which is similar to that for the complex $\mathbf{1 b}$. For the complex $\mathbf{2}$, its cationic binuclear structure and the cell packing diagram are shown in Figures 4 and 5, respectively.

Table 2. Selected bond lengths $(\AA)$ and angles $\left(^{\circ}\right)$ for complexes 1a, $1 \mathrm{~b}$ and 2.

\begin{tabular}{lrrr}
\hline & $\mathbf{1 a}$ & $\mathbf{1 b}$ & \multicolumn{1}{c}{$\mathbf{2}$} \\
\hline Cu1-N1 & $2.346(8)$ & $2.344(6)$ & $2.324(12)$ \\
Cu1-N3 & $2.049(8)$ & $2.029(6)$ & $2.028(9)$ \\
Cu1-N4 & $1.993(8)$ & $2.012(6)$ & $2.022(10)$ \\
Cu1-N5 & $2.062(8)$ & $1.992(7)$ & $1.983(11)$ \\
Cu1-N6 & $2.001(7)$ & $2.000(6)$ & $2.022(11)$ \\
Cr1-C1 & $2.078(11)$ & $2.121(9)$ & $2.103(11)$ \\
Cr1-C2 & $2.048(12)$ & $2.058(8)$ & $2.068(11)$ \\
Cr1-N7 & $1.984(8)$ & $1.967(6)$ & $1.971(9)$ \\
Cr1-N8 & $1.976(7)$ & $1.971(6)$ & $2.123(10)$ \\
Cr1-N9 & $2.063(7)$ & $2.083(6)$ & $1.972(9)$ \\
Cr1-N10 & $2.070(8)$ & $2.093(6)$ & $2.098(9)$ \\
Cu1-N1-C1 & $139.0(9)$ & $141.7(7)$ & $159.2(10)$ \\
Cr1-C1-N1 & $165.7(10)$ & $165.6(7)$ & $172.7(11)$ \\
Cr1-C2-N2 & $176.7(11)$ & $178.8(7)$ & $175.2(12)$ \\
\hline
\end{tabular}

The complexes $\mathbf{1 a}$ and $\mathbf{1 b}$ as a pair of enantiomer, containing $\mathrm{Cr}_{2} \mathrm{Cu}_{2}$ unit in the unit cell with a dimer structure, crystallize in monoclinic cell setting with the non-central space group $P 2_{1}$, while complex 2 crystallizes in triclinic cell setting with the non-central space group $P 1$. All the three complexes are with the similar cationic cyanide-bridged binuclear structure and the different balance anion, i.e. the free $\mathrm{ClO}_{4}{ }^{-}$for complexes $\mathbf{1 a}, \mathbf{1 b}$ and the free cyanide building block for complex 2 . The distances between the $\mathrm{O}$ atom of the $\mathrm{ClO}_{4}^{-}$ion and the $\mathrm{Cu}(\mathrm{II})$ ion is about $3.273 \AA$, indicating the existed weak interaction. In

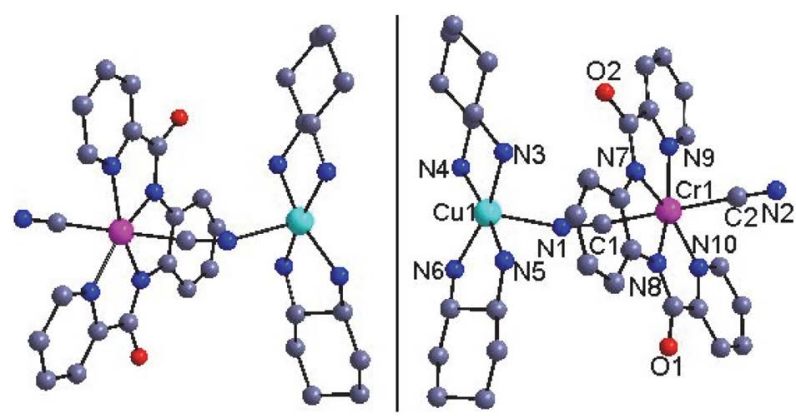

Figure 2. The perspective view of the enantiomeric structure of complexes $\mathbf{1 a}$ and $\mathbf{1 b}$. All the $\mathrm{H}$ atoms, the balanced anion and the solvent molecules have been omitted for clarity.

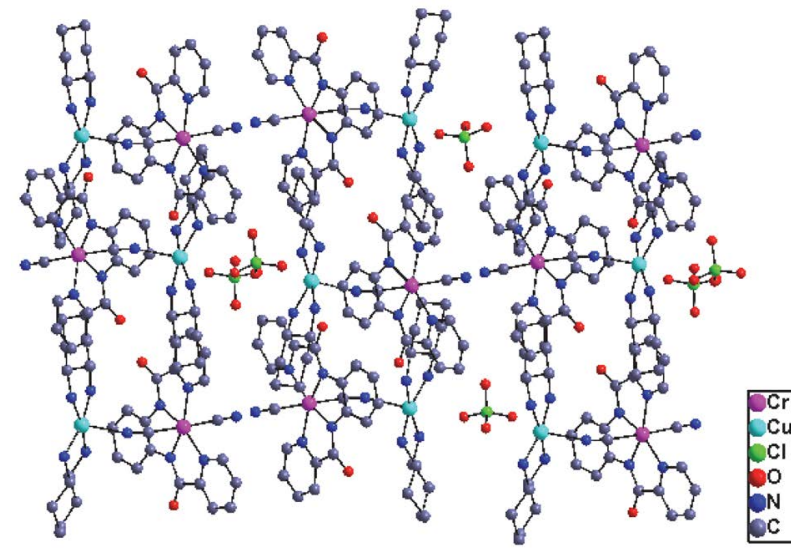

Figure 3. The cell packing diagram along $c$ axis of the complex 1a. All the $\mathrm{H}$ atoms and the solvent molecules have been omitted for clarity.

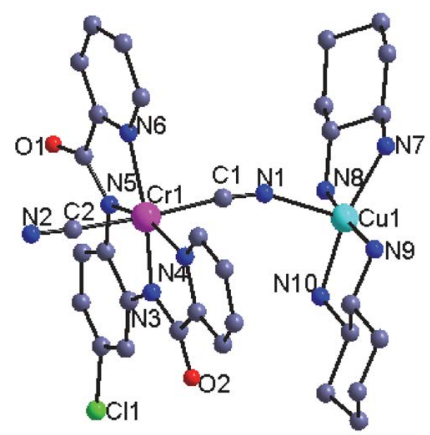

Figure 4. Perspective view of the cationic structure of the complex 2. All the $\mathrm{H}$ atoms, the balanced anion and the solvent molecules have been omitted for clarity.

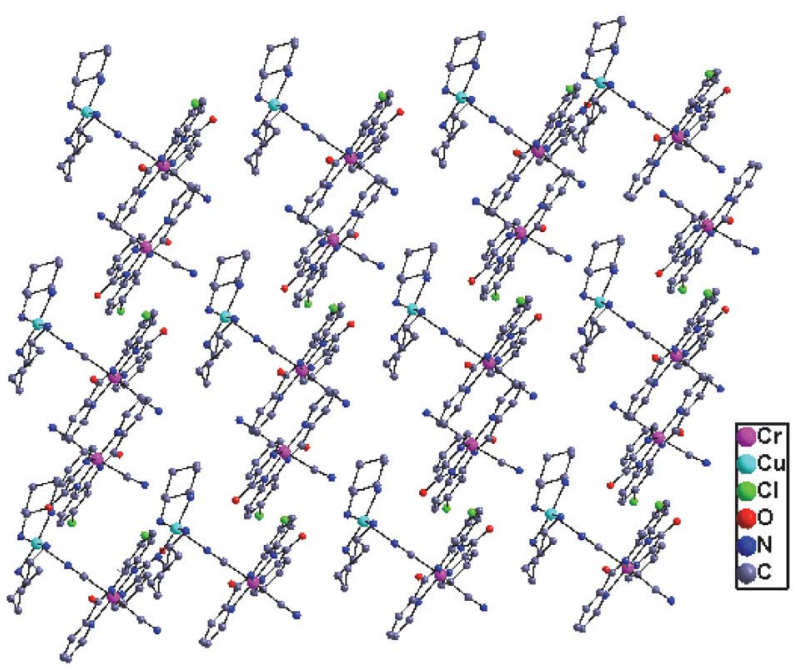

Figure 5. The cell packing diagram along $b$ axis of the complex 2 . All the $\mathrm{H}$ atoms and the solvent molecules have been omitted for clarity.

all the reported complexes, each cyanide-containing building block acting as a monodentate ligand through one of its two trans cyanide groups connects the $\mathrm{Cu}(\mathrm{II})$ ion with the other cyanide group as terminal. The Cr(III) ion 
is six-coordinates with four equatorial nitrogen atoms from the pyridinecarboxamide ligand and two carbon atoms from the two cyanide groups with a trans position, so that forming a slightly distorted octahedral geometry, which can be proven by the bond parameters around the $\mathrm{Cr}$ (III) ion (Table 2). The $\mathrm{Cr}-\mathrm{C} \equiv \mathrm{N}$ bond angles in these three complexes are in a comparatively narrow range of $165.6(7)^{\circ}-178.8(7)^{\circ}$, showing almost the linear conformation for these three atoms.

The $\mathrm{Cu}$ atom in complexes $\mathbf{1 a}, \mathbf{1 b}$ and $\mathbf{2}$ is five-coordinated by a $\mathrm{N}_{5}$ unit, in which four $\mathrm{N}$ atoms come from the two chiral amine ligands and the additional one $\mathrm{N}$ atom from the bridging cyanide group. The $\mathrm{Cu}$ atom is only out of the plane formed by four $\mathrm{N}$ atoms $0.16(2), 0.17(4)$ and $0.058(2) \AA$ toward to the fifth coordinated $\mathrm{N}_{\text {cyanido }}$ atom in these three complexes, indicating that these five atoms are almost located in a plane. The average $\mathrm{Cu}-\mathrm{N}_{\text {amine }}$ bond lengths in complexes $\mathbf{1 a}, \mathbf{1 b}$ and $\mathbf{2}$ are 2.009, 2.008 and $2.014 \AA$, respectively, obviously shorter than the $\mathrm{Cu}-\mathrm{N}_{\mathrm{cy}}$ anido bond length with the values of 2.346, 2.344 and 2.324 $\AA$, clearly showing the markedly distorted square pyramid surrounding of the $\mathrm{Cu}(\mathrm{II})$ ion. Additionally, it should be pointed out that there exists conspicuous difference for the $\mathrm{C} \equiv \mathrm{N}-\mathrm{Cu}$ bond angles in these three complexes. The $\mathrm{C} \equiv \mathrm{N}-$ $\mathrm{Cu}$ bond angle in complexes $\mathbf{1 a}$ and $\mathbf{1 b}$ are only $139.0(9)^{\circ}$, $141.7(7)^{\circ}$, respectively, while the corresponding angle in the complexes 2 is obviously larger than those in complexes $\mathbf{1 a}$ and $\mathbf{1 b}$ with value $159.2(10)^{\circ}$. The intramolecular $\mathrm{Cr}(\mathrm{III})-\mathrm{Cu}$ (II) separation through bridging cyanide group are 5.076, 5.098 and $5.412 \AA$ for these three complexes, which are obviously shorter than the shortest intermolecular metal-metal distance with the values of 6.519, 7.543, 8.108 and $7.511 \AA$ in the three complexes, respectively.

\section{3. The Magnetic Properties of Complexes}

Figure 6 shows the temperature dependences of magnetic susceptibility of complexes $\mathbf{1 a}$ and $\mathbf{2}$ measured in the temperature range of $2-300 \mathrm{~K}$ in the applied field of
2000 Oe. The room temperature $c_{\mathrm{m}} T$ values are 2.13 and $4.09 \mathrm{emu} \mathrm{K} \mathrm{mol}{ }^{-1}$ for these two complexes, respectively, which are slightly lower than the spin only value of 2.25 emu $\mathrm{K} \mathrm{mol}^{-1}$ for one uncoupled $\mathrm{Cu}(\mathrm{II})(S=1 / 2)$ ion and one $\mathrm{Cr}(\mathrm{III})(S=3 / 2)$ ion in complex 1a and $4.125 \mathrm{emu} \mathrm{K}$ $\mathrm{mol}^{-1}$ for one uncoupled $\mathrm{Cu}(\mathrm{II})(S=1 / 2)$ ion and two $\operatorname{Cr}$ (III) $(S=3 / 2)$ ion in complex 2 based on $g=2.00$. With the temperature decreasing, the $c_{\mathrm{m}} T$ values increases gradually and attains the value of 2.37 and $6.76 \mathrm{emu} \mathrm{K} \mathrm{mol}{ }^{-1}$ about $15 \mathrm{~K}$, then decreases sharply to 1.51 and $4.51 \mathrm{emu} \mathrm{K}$ $\mathrm{mol}^{-1}$ at $2 \mathrm{~K}$, which indicated the characteristic of ferromagnetic coupling between the cyanide-bridged $\mathrm{Cr}(\mathrm{III})$ $\mathrm{Cu}$ (II) center. The magnetic susceptibility for these two complexes conforms well to Curie-Weiss law in the range $2-300 \mathrm{~K}$ and give the positive Weiss constant $q=1.38 \mathrm{~K}$ and Curie constant $C=2.15 \mathrm{emu} \mathrm{K} \mathrm{mol}^{-1}$ for complex 1a and $q=7.01 \mathrm{~K}$ and Curie constant $C=4.15 \mathrm{emu} \mathrm{K} \mathrm{mol}{ }^{-1}$ for complex 2, further proves the ferromagnetic coupled $\mathrm{Cr}(\mathrm{III})-\mathrm{Cu}(\mathrm{II})$ through the cyanide bridge.

On the basis of the binuclear model, the magnetic susceptibility of complex 1a can be fitted accordingly by the following expression (1) derived from the isotropic exchange spin Hamilton $\hat{H}=-2 J \hat{S}_{C u} \hat{S}_{\mathrm{Cr}}$. For complex 2, its magnetic susceptibility has been analyzed based-on also the binuclear model but by introducing the additional isolated $\mathrm{Cr}(\mathrm{III})$ ion with the expression (2).

$$
\begin{aligned}
& \chi_{\mathrm{m}}=\frac{N g^{2} \beta^{2}}{k T} \cdot \frac{2+10 \exp (4 J / k T)}{3+5 \exp (4 J / k T)} \\
& \chi_{\mathrm{m}}=\frac{N g^{2} \beta^{2}}{k T} \cdot \frac{2+10 \exp (4 J / k T)}{3+5 \exp (4 J / k T)}+\frac{N g^{2} \beta^{2}}{3 k T} S_{C r}\left(S_{C r}+1\right)
\end{aligned}
$$

By using the above model, the susceptibilities over the temperature range of $2-300 \mathrm{~K}$ for these two complexes were simulated, giving the best-fit parameters $J=0.74(2)$ $\mathrm{cm}^{-1}, \mathrm{~g}=2.01(2), R=\sum\left(\mathrm{c}_{\mathrm{obsd}} T-\mathrm{c}_{\text {cald }} T\right)^{2} / \Sigma\left(\mathrm{c}_{\mathrm{obsd}} T\right)^{2}=2.30$ $\times 10^{-5}$ for $\mathbf{1 a}$ and $J=2.37(2), \mathrm{g}=2.01(8), R=3.21 \times 10^{-5}$ for 2 , respectively, which can further proven the weak ferro-
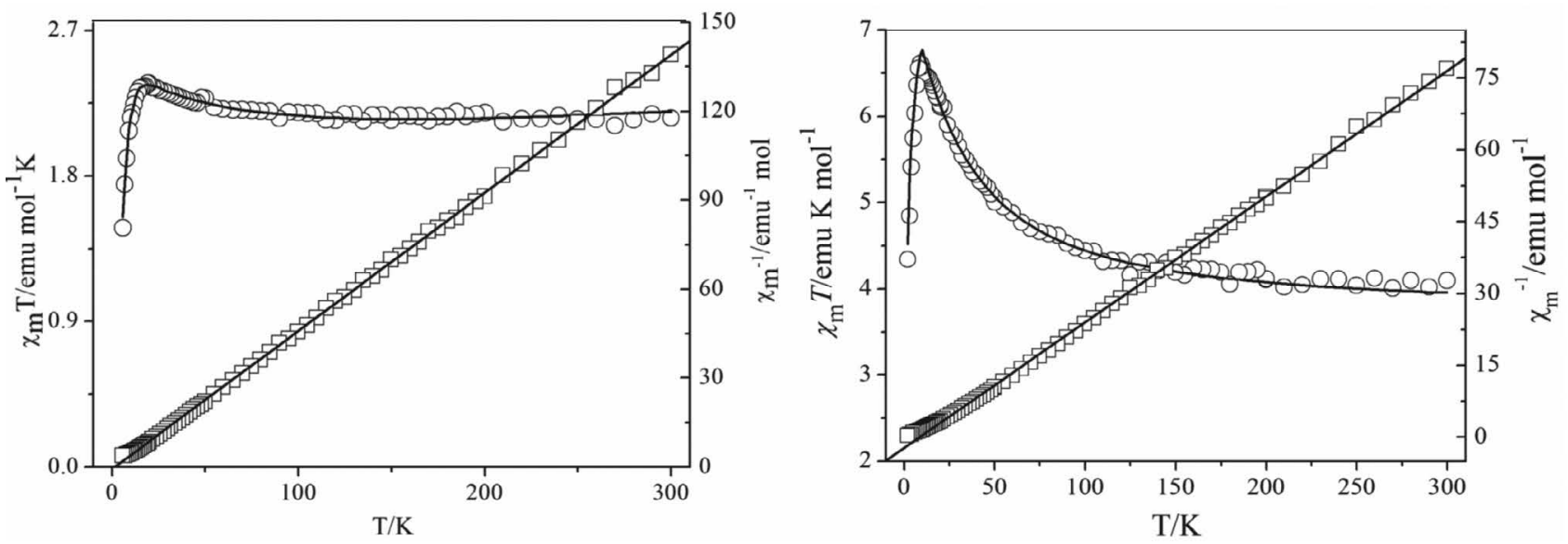

Figure 6. The $c_{\mathrm{m}} T$ and $\mathrm{c}_{\mathrm{m}}{ }^{-1} v s T$ curves for complexes $1 \mathrm{a}$ (left) and $\mathbf{2}$ (right). 
magnetic coupling between the $\mathrm{Cr}$ (III) ion and $\mathrm{Cu}$ (II) ion through the bridging cyanide group.

\section{Conclusion}

In summary, three new chiral cyanide-bridged heterobimetallic complexes, in which two of them are a pair of enantiomers, have been designed and successfully synthesized based on the chiral amine copper(II) compounds and the trans-dicyanidochromium(III)-containing building blocks. All the three complexes present the similar cationic cyanide-bridged binuclear structure but with different balanced anion, giving the information that the cyanide precursors with slight structural difference still have some influence on the forming of the target complexes. Investigation over the magnetic properties of the reported complexes reveals that the ferromagnetic coupling between the cyanide-bridged $\mathrm{Cr}(\mathrm{III})-\mathrm{Cu}(\mathrm{II})$ center.

\section{Acknowledgement}

This work was supported by the Natural Science Foundation of China (21671121) and the Natural Science Foundation of Shandong Province (ZR2018BB002).

\section{References}

1. P. Zhang, Y. N. Guo, J. Tang, Coord. Chem. Rev. 2013, 257, 1728-1763. DOI:10.1016/j.ccr.2013.01.012

2. Z. S. Yao, S. Q. Wu, Y. Kitagawa, S. Q. Su, Y. G. Huang, G. L. Li, Z. H. Ni, H. Nojiri, Y. Shiota, K. Yoshizawa, S. Kang, S. Kanegawa, O. Sato, Angew. Chem. Int. Ed. 2017, 56, 717-721. DOI:10.1002/anie.201606165

3. O. Sato, Nat. Chem. 2016, 8, 644-656.

DOI: $10.1038 /$ nchem. 2547

4. R. J. Wei, Q. Huo, J. Tao, R. B. Huang, L. S. Zheng, Angew. Chem. Int. Ed. 2011, 50, 8940-8943.

DOI:10.1002/anie.201103648

5. L. M. C. Beltran, J. R. Long, Acc. Chem. Res. 2005, 38, 325-334. DOI:10.1021/ar040158e

6. S. Wang, X. H. Ding, Y. L. Li, W. Huang, Coord. Chem. Rev. 2012, 256, 439-464. DOI:10.1016/j.ccr.2011.10.029

7. Y. H. Li, W. R. He, X. H. Ding, S. Wang, L. F. Cui, W. Huang, Coord. Chem. Rev. 2012, 256, 2795-2815.

DOI:10.1016/j.ccr.2012.09.014

8. M. Shatruk, C. Avendano, K. R. Dunbar, Prog. Inorg. Chem. 2009, 56, 155-334. DOI:10.1002/9780470440124.ch3

9. J. H. Lim, J. H. Yoon, S. Y. Choi, D. W. Ryu, E. K. Koh, C. S. Hong, Inorg. Chem. 2011, 50, 1749-1757.

DOI:10.1021/ic102179n

10. H. Miyasaka, A. Saitoh, S. Abe, Coord. Chem. Rev. 2007, 251, 2622-2664. DOI:10.1016/j.ccr.2007.07.028

11. Q. L. Wang, H. Southerland, J. R. Li, A. V. Prosvirin, H. Zhao,
K. R. Dunbar, Angew. Chem. Int. Ed. 2012, 51, 9321-9324. DOI:10.1002/anie.201203309

12. J. G. DaSilva, J. S. Miller, Inorg. Chem. 2013, 52, 1418-1423. DOI:10.1021/ic302148s

13. J. W. Shi, W. L. Wen, Y. Zhou, C. C. Xue, Q. Y. Liu, D. P. Zhang, J. Chem. Sci. 2018, 130, 19-27.

DOI:10.1007/s12039-018-1420-9

14. I. Y. Yoo, D. W. Ryu, J. H. Yoon, A. R. Sohn, K. S. Lim, B. K. Cho, E. K. Koh, C. S. Hong, Dalton Trans. 2012, 41, 17761785. DOI:10.1039/C1DT11293G

15. E. Pardo, M. Verdaguer, P. Herson, H. Rousselière, J. Cano, M. Julve, F. Lloret, R. Lescouězec, Inorg. Chem. 2011, 50, 62506262. DOI:10.1021/ic200616p

16. J. W. Shi, C. C. Xue, L. Q. Kong, D. P. Zhang, Acta Chim. Slov. 2017, 64, 215-220. DOI:10.17344/acsi.2016.3132

17. M. Ferbinteanu, H. Miyasaka, W. Wernsdorfer, K. Nakata, K. Sugiura, M. Yamashita, C. Coulon, R. Clérac, J. Am. Chem. Soc. 2005, 127, 3090-3099. DOI:10.1021/ja0468123

18. X. Chen, S. Q. Wu, A. L. Cui, H. Z. Kou, Chem. Commun. 2014, 50, 2120-2122. DOI:10.1039/c3cc48117d

19. D. P. Zhang, L. F. Zhang, Y. T. Chen, H. L. Wang, Z. H. Ni, W. Wernsdorfer, J. Z. Jiang, Chem. Commun. 2010, 46, 35503552. DOI: $10.1039 / \mathrm{b} 926710 \mathrm{~g}$

20. T. D. Harris, M. V. Bennett, R. Clérac, J. R. Long, J. Am. Chem. Soc. 2010, 132, 3980-3988. DOI:10.1021/ja910963x

21. H. R. Wen, C. F. Wang, Inorg. Chem. 2006, 45, 8942-8949. DOI:10.1021/ic060928d

22. J. I. Kim, H. S. Yoo, E. K. Kho, H. C. Kim, C. S. Hong, Inorg. Chem. 2007, 46, 8481-8483. DOI:10.1021/ic701361a

23. H. Y. Kwak, D. W. Ryu, J. W. Lee, J. H. Yoon, H. C. Kim, Inorg. Chem. 2010, 49, 4632-4642. DOI:10.1021/ic100301q

24. S. Huh, K. T. Youm, Y. J. Park, A. J. Lough, M. Ohba, Bull. Korean Chem. Soc. 2006, 26, 1031-1032.

25. F. L. Yang, J. Tao, R. B. Huang, L. S. Zheng, Inorg. Chem. 2011, 50, 911-917. DOI:10.1021/ic101490a

26. M. Andruh, J. P. Costes, C. Diaz, S. Gao, Inorg. Chem. 2009, 48, 3342-3359. DOI:10.1021/ic801027q

27. L. Catala, T. Cacoin, J. P. Boilot, T. Mallah, Adv. Mater. 2003, 15, 826-829. DOI:10.1002/adma.200304696

28. H. Z. Kou, S. Gao, B. Q. Ma, D. Z. Liao, Inorg. Chem. Commun. 2000, 713-714. DOI:10.1039/b001005g

29. X. P. Shen, H. B. Zhou, Q. Zhang, Y. Xu, H. Zhou, Eur. J. Inorg. Chem. 2012, 31, 5050-5057. DOI:10.1002/ejic.201200480

30. Y. Pei, Y. Journaux, O. Kahn, Inorg. Chem. 1989, 28, 100-103. DOI:10.1021/ic00300a023

31. J. J. Sokol, M. P. Shores, J. R. Long, Inorg. Chem. 2002, 41, 3052-3054. DOI:10.1021/ic0255499

32. M. X. Yao, Q. Zheng, X. M. Cai, Y. Z. Li, J. L. Zuo, Inorg. Chem. 2012, 51, 2140-2149. DOI:10.1021/ic201982d

33. C. Pichon, T. Senapati, R. Ababei, C. Mathonière, R. Clérac, Inorg. Chem. 2012, 51, 3796-3812.

DOI:10.1021/ic2027708

34. D. P. Zhang, Z. D. Zhao, P. Wang, Z. H. Ni, CrystEngComm. 2013, 15, 2504-2511. DOI:10.1039/c3ce27064e

35. D. P. Zhang, W. J. Si, P. Wang, X. Chen, J. Z. Jiang, Inorg. Chem. 2014, 53, 3494-3502. DOI:10.1021/ic4029386 
36. J. W. Shi, W. L. Lan, Y. J. Ren, Q. Y. Liu, H. Liu, Y. H. Dong, D. P. Zhang, J. Solid State Chem. 2018, 260, 59-66.

DOI:10.1016/j.jssc.2018.01.017

37. J. W. Shi, Q. G. Meng, C. C. Xue, Q. Y. Liu, D. P. Zhang, Transit. Metal Chem. 2018, 43, 45-52.

DOI:10.1007/s11243-017-0192-2

38. H. Y. Zhang, L. Q. Kong, D. P. Zhang, J. Struct. Chem. 2015, 56, 1533-1539. DOI:10.1134/S0022476615080119

39. T. Shiga, G. N. Newton, J. S. Mathieson, T. Tetsuka, M. Nihei, L. Cronin, H. Oshio, Dalton Trans. 2010, 39, 4730-4733. DOI:10.1039/b925399h

40. J. Ru, F. Gao, T. Wu, M. X. Yao, Y. Z. Li, J. L. Zuo, Dalton Trans. 2014, 43, 933-936. DOI:10.1039/C3DT52951G

41. D. P. Zhang, Y. Z. Bian, J. Qin, P. Wang, X. Chen, Dalton Trans. 2014, 43, 945-949. DOI:10.1039/C3DT52996G

42. D. P. Zhang, S. P. Zhuo, H. Y. Zhang, P. Wang, J. Z. Jiang, Dalton Trans. 2015, 44, 4655-4664.

DOI:10.1039/C4DT03274H
43. D. P. Zhang, H. Y. Zhang, Polyhedron 2015, 100, 36-42. DOI:10.1016/j.poly.2015.07.024

44. M. Gruselle, C. Train, K. Boubekeur, P. Gredin, N. Ovanesyan, Coord. Chem. Rev. 2006, 250, 2491-2500.

DOI:10.1016/j.ccr.2006.03.020

45. O. Sereda, J. Ribas, H. Stoeckli-Evans, Inorg. Chem. 2008, 47, 5107-5113. DOI:10.1021/ic702234y

46. A. Biswas, A. Jana, S. Sarkar, H. A. Sparkes, Judith A.K. Howard, N. Aliaga-Alcalde, S. Mohanta, Polyhedron 2014, 74, 57-66. DOI:10.1016/j.poly.2014.02.037

47. M. Ray, R. Mukherjee, J. F. Richardson, R. M. Buchanan, J. Chem. Soc. Dalton Trans. 1993, 2451-2457.

DOI:10.1039/dt9930002451

48. Sheldrick G. M. (1997) SHELXTL97, Program for the Refinement of Crystal Structure, University of Göttingen, Germany.

\section{Povzetek}

Tri heterokovinske $\mathrm{Cr}(\mathrm{III})-\mathrm{Cu}(\mathrm{II})$ komplekse $\mathrm{z}$ mostovnim cianido ligandom s formulami $\left\{\left[\mathrm{Cu}\left(\mathrm{L}^{1}\right)_{2} \mathrm{Cr}\left(\mathrm{L}^{3}\right)(\mathrm{CN})_{2}\right]\right.$ $\left.\mathrm{ClO}_{4}\right\}_{2} \cdot \mathrm{CH}_{3} \mathrm{OH} \cdot \mathrm{H}_{2} \mathrm{O}\left(\mathbf{1 a}, \mathrm{L}^{1}=(S, S)\right.$-1,2-diaminocikloheksan, $\mathrm{H}_{2} \mathrm{~L}^{3}=1$,2-bis(piridin-2-karboksamido)benzen), $\left\{\left[\mathrm{Cu}\left(\mathrm{L}^{2}\right)_{2} \mathrm{Cr}\left(\mathrm{L}^{2}\right)(\mathrm{CN})_{2}\right] \mathrm{ClO}_{4}\right\}_{2} \cdot \mathrm{CH}_{3} \mathrm{OH} \cdot \mathrm{H}_{2} \mathrm{O}\left(\mathbf{1 b}, \mathrm{L}^{2}=(R, R)\right.$-1,2-diaminocikloheksan $)\left\{\left[\mathrm{Cu}\left(\mathrm{L}^{3}\right)_{2} \mathrm{Cr}\left(\mathrm{L}^{4}\right)(\mathrm{CN})_{2}\right]\left[\mathrm{Cr}\left(\mathrm{L}^{4}\right)\right.\right.$ $\left.\left.(\mathrm{CN})_{2}\right]\right\} \cdot \mathrm{CH}_{3} \mathrm{OH} \cdot 2 \mathrm{H}_{2} \mathrm{O}(2),\left(\mathrm{H}_{2} \mathrm{~L}^{4}=1,2\right.$-bis(piridin-2-karboksamido)-4-klorobenzen) smo pripravili s kombiniranjem trans-dicianidokromovega(III) strukturnega motiva in kiralnega bakrovega(II) kompleksa. Vse tri komplekse smo karakterizirali z elementno analizo, IR spektroskopijo in rentgensko strukturno analizo. Monokristalna rentgenska analiza razkrije, da oba enantiomerna kompleksa $\mathbf{1 a}$ in $\mathbf{1 b}$ ter kompleks $\mathbf{2}$ sodijo med s cianidnim mostom povezane kationske dvojedrne zvrsti s prisotnim $\mathrm{ClO}_{4}^{-}$ali cianidnim anion. Magnetne lastnosti kompleksov $1 \mathrm{a}$ in 2 kažejo šibko feromagnetno sklopitev med sosednjima $\mathrm{Cr}$ (III) in $\mathrm{Cu}(\mathrm{II})$ ionoma preko mostovnega cianido liganda. 